DOI http://dx.doi.org/10.4314/mlr.v7i12.7

\title{
Comments on FAO's Achievements toward a Public Domain in Plant Genetic Resources for Food and Agriculture
}

Robel Ephrem *

\section{1. "Public Domain" in "PGRFAs": An Overview}

I start this comment with the overview of "public domain" in relation to Plant Genetic Resources for Food and Agriculture (PGRFAs). What is basically challenged under arguments beneath the 'public domain' is the claim of proprietary right by private entities over knowledge that is created or derived

- Lecturer, School of Law, Dire Dawa University; (LL.B from Haramaya University in 2007, LL.M in Law in Development from University of Warwick, March 2011); author can be reached at <reachrobel@yahoo.com>

${ }^{1}$ Acronyms:

$\begin{array}{ll}\text { ABS } & \text { Access and Benefit Sharing } \\ \text { CBD } & \begin{array}{l}\text { Convention on Biological Diversity } \\ \text { FAO }\end{array} \\ \text { Food and Agriculture Organisation of the United Nations } \\ \text { IPR(s) } & \begin{array}{l}\text { Intellectual Property Right(s) } \\ \text { ITPGRFA }\end{array} \\ & \begin{array}{l}\text { International Treaty on Plant Genetic Resources for Food and } \\ \text { Agriculture }\end{array} \\ \text { IUPGR } & \text { International Undertaking on Plant Genetic Resources } \\ \text { MLS } & \text { Multilateral System under ITPGRFA } \\ \text { MTAs } & \text { Material Transfer Agreements } \\ \text { PGRs } & \text { Plant Genetic Resources } \\ \text { PGFRAs } & \text { Plant Genetic Resources for Food and Agriculture } \\ \text { PVP } & \text { Plant Variety Protection } \\ \text { TRIPS } & \text { Agreement on Trade Related Aspects of Intellectual Property Rights } \\ \text { UPOV } & \text { International Convention for the Protection of New Varieties of Plants } \\ \text { WTO } & \text { World Trade Organization }\end{array}$


from common resources with the purpose of regaining access to such common resources or claiming the share of the benefits derived by the private entity. Strathern notes the challenge stating that a resource belonging to the public domain remains in such domain, and underlines that "once public, it cannot be subject of proprietary claims".

The 'public domain' in relation to intellectual property rights is claimed to be '(unlike the commons), a residual category created by intellectual property regimes themselves' and that it is often confused with the 'commons'. Horowitz asks "if the public domain is nothing more than the holes in the intellectual property system, why reify it with theory and metaphor?" Still, Horowitz seems to endorse the answer from Boyle that 'language matters' which emanates from the fear that the 'commons' are in danger of 'enclosure'. If we allow the 'property-centered approach to information' it will certainly make 'the public domain' disappear from the public consciousness. ${ }^{5}$

Most notably there is the danger that: "well-organized groups (such as the pharmaceutical companies) with stable, substantial and well defined interests face off against diffuse groups (the public) with high information costs whose interests, while enormous in the aggregate, are individually small". 6 Accordingly, this would result in an increased exclusion of the public by such 'enclosure' of the 'commons' and the need arises, at least, to maintain a public space that enables 'free access' if reclaiming of the 'commons' proves to be impossible.

Various scholars try to come up with different definitions for the 'public domain' depending upon what each perspective wants to justify. The competing interests and perspectives can, for instance, be in favor of intellectual property rights or in pursuance of limiting the extent of such protection. ${ }^{7}$ Although definitions are surrounded by 'metaphor', the 'public domain' can be described as:

...an institutional space, where human agents can act free of the particular constraints [such as property rights] required for markets, and where they

${ }^{2}$ M. Strathern (2006). 'Intellectual Property and Rights: Anthropological Critique'. In C. Tilley et al. (eds.) Handbook of Material Culture: Sage, p. 453.

${ }^{3}$ Ibid.

${ }^{4}$ S. J. Harowitz (2009). 'Designing the Public Domain'.Harvard Law Review [Online]. Vol. 122, No. 5.[Accessed $7^{\text {th }}$ Jan, 2010], pp. 1491. Available from World Wide Web: $<$ http:// www.ssrn.com>

${ }^{5}$ Ibid.

${ }^{6}$ Ibid.

${ }^{7}$ See J. Boyle (2003). 'The Second Enclosure Movement and the Construction of the Public Domain'. Law and Contemporary Problems, 66 (1\&2), p. 60. 
have some degree of confidence that the resources they need for their plans will be available to them. ${ }^{8}$

It may, however, be questioned as to whether the 'public domain' is the same as the concept of the 'common heritage' of mankind referred above as 'commons'. Chander and Sunder argue that this concept may not be as romantic as we think. ${ }^{9}$ The mere fact that a resource belongs to the commons does not necessarily mean equal sharing in the utilization of such resources. According to Strathern, "common property rights imply co-equal ownership of rights, not equal shares to resources...". ${ }^{10}$ Co-equal ownership rights in the form of group or 'corporate entity' gives individual members of the group the right to usufruct. How such usufruct rights may be managed could be diverse which likely impacts the sharing of the resource owned collectively. Thus, the ultimate surety that the group can get is that "the group's ownership cannot be extinguished by the actions of individuals". 11

One noteworthy point, to be drawn from Strathern, is that we find a different notion in the concept of 'public domain' that it inherently endorses the existence of some form of private proprietary ownership and tries to save for the public a common pool especially on areas where public interest is dominant. In this regard, it is important to take note of Boyle's suggestion to be wary of long standing critics of 'anti-commons' that work in favor of enclosure since such claim of inherent endorsement could work in favor of more enclosure of the 'commons' to the private domain. ${ }^{12}$

Predominantly, what lies at the heart of the controversy resulting from claim of proprietary rights by private entities and subsequent denial of the public from access to such knowledge or resources is the issue of regaining 'access'. Hence, an effort to carve out a public domain would be the logical next step to be taken towards attaining this end. Such effort in relation to Plant Genetic Resources for Food and Agriculture (hereafter, PGRFAs) can be specifically appreciated to ensure access to such resources (e.g. seeds) for farmers against a claim of proprietary right by private entities that deny farmers their access to plant genetic resources or specifically PGRFAs.

Unfortunately, as Andersen states, legal restrictions on access to genetic resources have intensified the problem of the current genetic erosion in crop

\footnotetext{
${ }^{8}$ Harowitz (supra note 4).

${ }^{9}$ A. Chander \& M. Sunder (2004). 'The Romance of the Public Domain'. California Law Review: Vol. 92, No. 5, p. 2.

${ }^{10}$ Strathern, supra note 2, p. 454.

${ }^{11}$ Ibid.

${ }^{12}$ Boyle, supra note 7, p. 36.
} 
varieties which heightens food insecurity. ${ }^{13}$ These restrictions are of two forms: "intellectual property rights to plant genetic resources, and acts and regulations at the national level in a range of countries governing access to genetic resources" $" 14$.

The controversy between patents or plant breeders' rights and regulation of access to plant genetic resources entails two forms of denial of access. The first factor relates to national regulation denying access to plant genetic resources from the centers of origin ${ }^{15}$ such as Ethiopia. This is exacerbated by the diversity of those multinational companies and research centers even if this can be a moot issue considering the weaker bargaining position of developing countries. The second factor in the denial of access is the grant of exclusive monopoly rights (patents or plant breeders' rights).

Both forms of denial denote that any person must make payment in order to get access to plant genetic resources. While the status quo of plant genetic resources is in a state of devastating erosion, grants of such intellectual property rights deny the wider public and mainly farmers access to varieties that are collected or to varieties derived from the plant genetic resources available in the open source without any form of benefit-sharing.

Arguments based on the public domain 'theory' cannot be raised to get rid of intellectual property right claims and protection over plant genetic resources by private entities especially if we submit to Strathern's definition of the public domain as 'a residual category' that inherently endorses private monopoly rights. Such arguments may, however, be helpful in carving out a domain that enables free access to the 'public'.

The question that comes into one's mind will then be how it would be possible for the International Treaty on Plant Genetic Resources for Food and Agriculture (ITPGRFA) to ensure access to PGRFAs within a system that grants an exclusive or monopoly right over plant genetic resources to a private entity.

\section{Background on PGRFAs}

The International Undertaking on Plant Genetic Resources (IUPGR) was FAO's effort (in 1983) to potentially go beyond ensuring access to plant genetic resources and make a stronger claim of treating all plant genetic resources (PGRs) as "common heritage" of mankind. It was a non-binding instrument

${ }^{13}$ R. Andersen (2003). 'FAO and the Management of Plant Genetic Resources' In O. Stokke \& Ø. Thommessen (eds.), (2003/2004): Yearbook of International Cooperation on Environment and Development. London: Earthscan, p. 2.

${ }^{14}$ Ibid.

${ }^{15} \mathrm{See}<\mathrm{http}$ //www.ibc.gov.et/biodiversity/components-of-biodiversity/plant-speciesdiversity $>$. 
which did not provide for a public domain treatment but rather "took the position that all PGRs were to be treated as the common heritage of mankind". ${ }^{16}$ It provided broad definition of "common heritage" that included commercial plant varieties protected by plant breeders' rights and plant patents in some jurisdictions and multilateral treaties of the developed nations. The underlying motive was that "if the PGRs of the developing world were freely appropriable, so too should be the proprietary varieties of the developed countries". ${ }^{17}$ The International Undertaking on Plant Genetic Resources (IUPGR) never got wide acceptance (or failed) to culminate into a binding treaty mainly due to clear difference of the positions of the developed and developing countries.

Then, followed the negotiation, known as the "keystone dialogue", between the developed and the developing countries that resulted in "a recognition by the developing countries of the validity of IPRs [Intellectual Property Rights] in plant varieties" and that "common heritage" or free accessibility to and appropriation of farmers' landraces located in developing countries by developed countries did not mean access free of charge." 18 The focus of the dialogue in the international regimes, afterwards, was channeled to the issue of ensuring access and benefit sharing which was promoted by developing countries after having submitted to the validity of IPRs in plant varieties during the keystone dialogue.

The 1992 Convention on Biological Diversity (CBD) addresses the issues of access to genetic resources. Although it does not specifically refer to PGRFAs, it allows countries to put conditions for access based on "environmentally sound reasons" since the convention is mainly concerned about the conservation of biodiversity. ${ }^{19}$ It also recognizes the sovereign rights of states over their PGRs ${ }^{20}$

On the other hand, the TRIPS (Trade Related Aspects of Intellectual Property Rights) Agreement under the World Trade Organization's legal regime demands

${ }^{16}$ M. Blakeney (1998). 'Access to Biological Resources: Domestic and International Developments and Issues'. MUEJL [Online].Vol. 5, No. 3.[Accessed 7 Jan, 2010], p. 4. Available from World Wide Web: $<$ http://www.murdoch.edu.au/elaw/issues/v5n3/blakeney53.html $>$

${ }^{17}$ K. Aoki \& K. Luval (2007). "Reclaiming 'Common Heritage' Treatment in the International Plant Genetic Resources Regime Complex". Michigan State Law Review: Vol.1, p. 41.

${ }^{18}$ Ibid.

${ }^{19}$ Convention on Biological Diversity (CBD): Rio de Janeiro, (1992), Article 15. Also see: Varella (2003). Access to Genetic Resources and Benefit Sharing: Main Aspect of Some Legal Frameworks. Open meeting of the Global Environmental Change Research Community: p. 9. Available from World Wide Web: $<$ http:// www.ssrn.com/abstract $=674502>$

${ }^{20}$ Aoki \& Luval, supra note 17, p. 49. 
protection of plant varieties by patents or sui generis system of protection (or a combination of the two). ${ }^{21}$ UPOV (International Convention for the Protection of New Varieties of Plants) has been considered by developed nations as a model for sui generis ("of its own kind", i.e. a similar protection to patent right) as its provisions favor the interest of the developed nations. Provisions of UPOV provide protection similar to patent and most of UPOV members are industrialized countries. $^{22}$ In 2001, some amendments were, introduced ${ }^{23}$ based on the 'keystone dialogue'.

\section{The International Treaty on Plant Genetic Resources for Food and Agriculture (ITPGRFA)}

The objective of the treaty is the conservation and sustainable use of PGRFAs and the fair and equitable sharing of the benefits arising out of their use so as to ensure sustainable agriculture and food security. ${ }^{24}$ The ITPGRFA establishes a MLS (Multilateral System under ITPGRFA) as a "communal seed treasury". 25 Under Annex I, it specifies list of "most central food plants" 26 that are in the MLS and in the public domain as envisaged in Article 11.2. As Rosendal notes:

... the material, it is agreed, must remain freely available and not become subject to patents 'in the form received' from the FAO multilateral system, that is, international gene banks (Article 12.3). It is meant to contribute to securing farmers' rights to use and reuse their seeds and to retain access to breeding material. ${ }^{27}$

The presumption is that there would be no Intellectual Property Rights to claim without some modification to the PGRFAs. This is because PGRFAs "in the

${ }^{21}$ WTO (1994), Agreement on Trade Related Aspects of Intellectual Property Rights (TRIPS), Geneva: WTO, Article 27.3 (b).

22 "Intellectual Property Rights: Ultimate control of agricultural R\&D in Asia" $<$ http://www.grain.org/article/entries/30-intellectual-property-rights-ultimate-controlof-agricultural-r-d-in-asia >, p.6

${ }^{23}$ Aoki \& Luval, supra note 17, p. 53

24 International Treaty on Plant Genetic Resources for Food and Agriculture (ITPGRFA), Article 1.1.

${ }^{25}$ L. R. Helfer (2004). 'Intellectual Property Rights in Plant Varieties: International Legal Regimes and Policy Options for National Governments'. Food and Agriculture Org. of the United Nations, FAO Legislative Study, No. 85, p. 87.

${ }^{26}$ G. K. Rosendal (2006). 'Balancing Access and Benefit Sharing and Legal Protection of Innovations from Bioprospecting - Impacts on Conservation of Biodiversity'. The Journal of Environment and Development [Online].Vol.15, No. 4.[Accessed December $\left.31^{\text {st }}, 2010\right]$, p. 434. Available from World Wide Web: <http:// jed.sagepub.com>

${ }^{27}$ Ibid. 
form received" from such MLS are in the public domain. ${ }^{28}$ The commercialization of PGRFAs "in the form received" from the MLS entails the obligation to share the benefits thereof with the contracting parties. ${ }^{29}$

In order to ensure the "facilitated access", the ITPGRFA provides for the material transfer agreement (MTA); an agreement between a "provider" and "recipient" which the GB (Governing Body under ITPGRFA) adopts. ${ }^{30}$ More specifically, "MTAs include a provision that prohibits commercial use of the material transferred, as well as further transfer to third parties. Almost all of the MTAs include a provision regarding intellectual property rights, with a view to either restrict protection by the recipient of the accessed material as such, or establish a benefit sharing scheme in events where accessed material or related traditional knowledge is improved." 31

The major shortcomings of ITPGRFA in promoting the public domain for PGRFAs are as discussed below.

\section{a) The Listing in Annex I of ITPGRFA}

Where ITPGRFA recognizes the sovereign rights of states over their own PGRFAs ${ }^{32}$, it is not clear why the "negotiated listing" of PGRFAs has excluded PGRs that may be essential for a certain state's food security. It has "notably",33 excluded PGRs such as "soybean (four instances), tomato (three), sugarcane (two), cassava (two), palm oil tree (two), peanut, groundnut, cucumber, pepper, and pear" and that the listing in Annex I is "too limitative". 34 Article 11.1 states that the listing in Annex 1 is based upon "criteria of food and security and interdependence. A point to note is that such exclusion goes against the very objective of the treaty especially when a certain essential PGR, "ought to" fall within PGRFAs' category. Such exclusion errodes ITPGRFA and indicates the difficulty to negotiate on specific listing of PGRFAs.

${ }^{28}$ C. R. McManis (2007). 'Facilitated Access and Benefit Sharing under the New FAO Treaty: The Interface of Open-Source and Proprietary Agricultural Innovation'. Washington University - IPSC: p. 7. Available in [PPT] from World Wide Web: < http://

www.law.depaul.edu/centers_institutes/ciplit/...ppt/Charles_McManisPPT.ppt $>$

${ }^{29}$ ITPGRFA (supra note 24), Article 13.

${ }^{30}$ Ibid, Article 12.4.

${ }^{31}$ M. Lightbourne (2006). 'Survey on the Concurrent Implementation of the FAO Treaty on Plant Genetic Resources and of Intellectual Property Rights'. Intellectual Property Quarterly. Vol. 2, p. 132.

32 ITPGRFA (supra note 24), Article 10.1.

${ }^{33}$ McManis, supra note 28, p. 4

${ }^{34}$ Lightbourne, supra note 31. 
b) Article 12.3 (b), ITPGRFA

This provision completely denies facilitated access to a country that cannot afford to pay such minimal fee. Thus, it retards the public domain by denying access to PGRFAs that are regarded by the treaty as falling within the public domain.

\section{c) Access to individual farmers and breeders}

This issue seems to have been neglected or otherwise intentionally left out from the treaty. As it is closely related to the purpose of the access sought to be facilitated in ITPGRFA, the issue needs examination of the phrase in Article 12.3 (a) which reads "[a]ccess shall be solely for the purpose of utilization and conservation for research, breeding and training for food and agriculture...". The provision tries to prevent access to those who may want to directly use the PGRFA for non-food industrial uses. ${ }^{35}$ The treaty, i.e. ITPGRFA should have as a matter of purpose ensured and promoted access to seeds (as Plant Genetic Resources for Food and Agriculture) for farmers and breeders as long as it is not used for direct commercial purpose. As the treaty is drafted on the basis of recognition of the sovereign rights of states over PGRs, it should not have been silent regarding issues relating to individual access. Unlike Helfer's ${ }^{36}$ assumptions, it may not be plausible to take a presumption that access is insured. In the absence of such access facilitation, the effort to carve out a public domain for PGRFAs seems to be largely unsuccessful, and the MLS (Multilateral System under ITPGRFA) should have embodied a mechanism to monitor states to this end in.

\section{d) Benefit sharing mechanism}

Once it is established that the listed PGRFAs are in the public domain, it follows that there is open access and that the commercialization of such PGRFAs entails a duty to share benefits. Article 13 provides for such arrangement. In fact, the fund from the benefit sharing will be used "to promote conservation and sustainable use of plant genetic resources, particularly by farmers and indigenous communities, whose rights and contributions the ITPGRFA expressly recognizes" 37 Since the focus of this comment is mainly on facilitated access to PGRFAs, I do not deal with benefit sharing in detail. But, two important points should be noted.

First, the provision has adopted mechanisms of benefit sharing such as exchange of information, access to and transfer of technology, capacity building,

\footnotetext{
35 “...provided that such purpose does not include chemical, pharmaceutical and/or other non-food/feed industrial uses", "ITPGRFA (supra note 24)", Article 12.3 (a).

${ }^{36}$ Helfer, supra note 25.

${ }^{37}$ Ibid.
} 
and sharing of monetary and other benefits of commercialization. These are mainly difficult to implement due to their vague nature and their dependence on the will of states. The second problem relates to the phrase in Article 13.2(d)(ii) which reads "...shall pay ... except whenever such product is available without restriction to others for further research and breeding...". This stipulation relives intellectual property right holders in PGRFAs of the obligation to share the benefits from commercialization merely because it is made available without restriction to others for further research and breeding. Various NonGovernmental Organizations (NGOs) argue that this would harm the MLS (Multilateral System under ITPGRFA) because it takes away the minimum fund $\left(0.77 \%\right.$ of the selling price) needed for strengthening the system. ${ }^{38}$

\section{e) Ambiguous issues in Article 12.3(d) of ITPGRFA}

McManis points out two ambiguous issues in Article 12.3(d) of ITPGRFA (International Treaty on Plant Genetic Resources for Food and Agriculture). The first is as to "how much of improvement or modification is required before a genetic component of a PGRFA is no longer "in the form received" under the MLS?" 39 From the reading of the provision, it is clear that a recipient of PGRFAs cannot claim patent or PVP (Plant Variety Protection) without some modification or "in the form received" from the MLS (Multilateral System under ITPGRFA). However, the provision does not deal with how and when a PGRFA is said to be no longer "in the form received" from the MLS.

McManis states that the scope of this provision will be influenced by the interpretation of other treaty provisions such as TRIPS as envisaged in Paragraph 10 of the preamble of ITPGRFA. It provides, "nothing in this treaty shall be interpreted as implying in any way a change in the rights and obligations of the Contracting parties under other international agreements". Accordingly, developed countries would argue (under FAO and WTO dispute settlement) that 'inventions' within the meaning of TRIPS are not genetic parts or components in the form received under the MLS. On the other hand, developing countries will likely argue that genetic components of PGRFAs are not 'inventions' within the meaning of TRIPS and thus fall within the MLS. Neither argument would solve the failure of the provision to provide specific guidelines to distinguish a PGRFA which is no longer in the form received from the MLS.

The second issue raised by McManis reads "under what circumstances do IPRs 'limit' facilitated access to PGRFAs?" ${ }^{40}$ It is stated in the provision that "[r]ecipients shall not claim any intellectual property or other rights that limit the

\footnotetext{
${ }^{38}$ McManis, supra note 28, p. 16.

${ }^{39}$ Ibid, p. 8.

${ }^{40}$ Ibid, p. 8-11.
} 
facilitated access" to PGRFAs or their genetic parts or components". Of the existing IPR forms in PGRs, PVP under UPOV or other Plant Patents have their own different effect on limiting facilitated access. PVPs are less restrictive since there is a mandatory exception such as for "acts done privately and for noncommercial use or acts done for experimental purposes". ${ }^{41}$ It can even arguably be said that PVPs do not 'limit' facilitated access. Patents for plants or genetic components are more problematic since they are governed by TRIPS.

Some may argue that 'limited exceptions' can be made under Article 30 of ITPGRFA and compulsory license issuing under Article 31. Yet, these may not be enough to clearly put instances that "limit" facilitated access. Even the MTA (Material Transfer Agreements) adopted by the GB (Governing Body under ITPGRFA) replicates the same problem. ${ }^{42}$ There should thus be is a clear demarcation of public domain which, at least, has guiding principles for distinguishing an IPR that limits facilitated access from one that does not. Otherwise, the point of carving out a public domain for PGRFAs becomes ineffective.

\section{f) ITPGRFA and the Regime Complex in PGRs}

The legal and practical effects of the ITPGRFA will not only depend on how much countries are willing to commit themselves to implementing it, but will also be influenced by its relationship with other agreements relevant to the PGRs regime such as the CBD, UPOV and TRIPS. ${ }^{43}$ Possible conflict with these treaties puts ITPGRFA in a weaker position of enforceability. Unlike the other treaties, TRIPS has 'teeth' whenever these treaties are in conflict, inter alia, due to retaliatory measures and sanctions. ${ }^{44}$

\section{Conclusion}

The need to limit exclusive intellectual property rights emanates from the "public interest'. ${ }^{45}$ To this end, the ITPGRFA (International Treaty on Plant Genetic

${ }^{41}$ International Convention for the Protection of New Varieties of Plants (UPOV), Article 15. Also see McManis, supra note 28, p. 12

${ }^{42}$ McManis, supra note 28, p. 16

${ }^{43}$ C. Gerstetter et al (2007). 'The International Treaty on Plant Genetic Resources for Food and Agriculture within the Current Legal Regime Complex on Plant Genetic Resources'. The Journal of World Intellectual Property [Online]. Vol. 10, Nos. 3/4. [Accessed $15^{\text {th }}$ January 2010], p. 259. Available from World Wide Web:

$<$ http:// www.interscience.wiley.com>

44 Aoki \& Luval, supra note 17 , p. 55

${ }^{45}$ C. M. Correa (2001). Options for the Implementation of Farmers' Rights at the National Level, 8, South Centre, Geneva: p. 3. Available from World Wide Web:

$<$ http:// www.southcentre.org $>$ 
Resources for Food and Agriculture) makes a prudent effort to ensure facilitated access to PGRFAs through MLS. It pursues a realistic approach to avoid conflict with the interest of developed nations while trying to facilitate access to plant genetic resources and to carve out the residual category of PGRFAs by giving recognition to plant patents and PVPs (Plant Variety Protection). However, this is confronted by the shortcomings discussed above which makes it selfcontradictory with its very objective. ITPGRFA is thus unable to effectively promote the public domain for PGRFAs in the midst of increasing pressure for the enclosure of biotechnology by the industrialized nations through international organizations such as the World Trade Organization. 